\title{
Probiotics as a Promising Treatment for Inflammatory Bowel Disease
}

\author{
Momir M. Mikov ${ }^{1,2,3}$, Maja P. Stojančević́ ${ }^{1}$ Gordana M. Bojić ${ }^{4}$ \\ ${ }^{1}$ Department of Pharmacology, Toxicology and Clinical Pharmacology, Faculty of Medicine, \\ University of Novi Sad, Novi Sad, Serbia; \\ ${ }^{2}$ School of Pharmacy, Curtin Health Innovation Research Institute, Curtin University, \\ Perth, WA, Australia; \\ ${ }^{3}$ School of Pharmacy, University of Montenegro, Podgorica, Montenegro; \\ ${ }^{4}$ Department of Microbiology, Institute of Public Health, Faculty of Medicine, \\ University of Novi Sad, Novi Sad, Serbia
}

\section{SUMMARY}

Treatment of chronic inflammatory gastrointestinal conditions such as inflammatory bowel disease (IBD) is difficult due to the ambiguity surrounding their precise etiology. Complex interaction of genetic, microbial and environmental factors leads to sustained activation of the mucosal immune system resulting in active inflammation. Despite the efficacy of conventional therapy, significant side effects can occur, highlighting the need for novel treatment approaches to IBD. Since gut microflora appears to play a significant role in IBD, manipulation of its composition and activity by administering beneficial bacteria - probiotics, has been identified as a potential therapeutic option. Probiotic bacteria are able to modify and improve the intestinal environment and subsequently reduce the severity of intestinal inflammation associated with IBD. Clinical evidence suggest that probiotics can maintain remission in Ulcerative colitis (UC) and Crohn's disease (CD) but there are no convincing reports on the effectiveness in patients with more severe active forms of IBD. This review will explore various mechanisms how probiotics may affect IBD and summarize the current knowledge regarding the role of probiotics in IBD.

Keywords: gut microflora; probiotics; inflammation; intestinal barrier; intestinal permeability

\section{INTRODUCTION}

Although much is known about the pathogenesis of inflammatory bowel disease (IBD), our understanding in that field still remains incomplete. As a consequence, IBD conditions are chronic debilitating states without cure [1]. The best accepted hypothesis is that the complex interaction of genetic, microbial and environmental factors results in a sustained activation of the mucosal immune system leading to active inflammation and tissue damage [2]. Under normal conditions, the host immune system is tolerant towards the antigens of the commensal gut microflora. Deregulation of the immune responses directed towards commensal bacteria 
is known to be involved in the initiation and development of IBD [3]. Although there is an increasing evidence that dysbiosis is considerably implicated in the etiology and pathogenesis of IBD, it is still unclear whether dysbiosis is a direct cause of the inflammation in IBD, or merely the result of disturbed environment in the gastrointestinal tract [4].

As the intestinal microflora appears to play a significant role in IBD, manipulation of its composition and activity by administering beneficial bacteria - probiotics, has been identified as a potential therapeutic option [5]. Positive effects of probiotics are generally attributed to their ability to normalize host intestinal flora, modulate the intestinal epithelial barrier of the host, block pathogen binding to or penetration of mucosal surfaces, prevent the pathogenic bacterial growth, stimulate mucosal barrier function, and equilibrate the balance between proinflammatory and anti-inflammatory cytokines and subsequently reduce the severity of the intestinal inflammation associated with IBD $[6,7]$. This review will explore various mechanisms by which probiotics may affect IBD and summarize the current knowledge regarding the role of probiotics in IBD.

\section{INFLAMMATORY BOWEL DISEASE}

Ulcerative colitis (UC) and Crohn's disease (CD) are two major forms of the inflammatory bowel disease (IBD). The hallmark of IBD is chronic, uncontrolled inflammation of the intestinal mucosa with potentially severe complications and even mortality. Diagnosis is based on the architectural distortion and/or acute inflammatory cells [8]. Clinical symptoms of IBD include abdominal pain, diarrhea, rectal bleeding, malaise as well as systemic symptoms of weight loss, fever and fatigue [3]. The main difference between CD and UC is the location and nature of the inflammatory changes. $\mathrm{CD}$ can involve any part of the gastrointestinal tract, although the majority of cases originates from the terminal ileum. Diseased segments are frequently separated by intervening normal bowel, leading to the term "skip areas". Inflammation can be transmural, often extending through to the serosa, resulting in sinus tracts or fistula formation. UC, in contrast, is limited to the colon and rectum. Inflammation is limited primarily to the mucosa and consists of continuous involvement of variable severity with ulceration, edema and hemorrhage along the colon [9]. The symptoms are similar to $\mathrm{CD}$, although there is no development of fistula. A great diversity of symptoms within UC and $\mathrm{CD}$ suggests distinct underlying pathogenetic mechanisms [10].

\section{Barrier function and the increased intestinal epithelial permeability in IBD}

This important defensive task of the intestine is based on three essential constituents: the microflora, the mucosal barrier, and the local immune system [11]. As we have already mentioned, all these factors have an important role in IBD that will be discussed in this chapter.

The intestinal epithelium constitutes the largest and most important barrier between the host and the luminal content of the intestine. It prevents the passage of harmful intraluminal entities, including foreign antigens, microorganisms, and their toxins. At the same time, the intestinal barrier has to be permeable for essential dietary nutrients, electrolytes and water, absorbed from the intestinal lumen into the circulation because of their importance for growth and development [12]. Healthy epithelium, with its highly evolved tight junctions (TJ) and transporter proteins, normally provides an effective barrier against luminal microbes and antigens [10]. Barrier function is regulated by a variety of factors produced by mucosal cells, enteric bacteria, and epithelial cells themselves. The role of enteric bacteria in regulating the barrier function has particularly become a very active area of research [13]. Disruption of this barrier can lead to loss of the immune tolerance to microflora and an inappropriate inflammatory response, as is thought to occur in the IBD [14].

Multiple molecular mechanisms of the increased intestinal permeability in patients with IBD have been reported, including reduction of TJ strands, strand breaks, alterations of TJ protein content and composition, and increased epithelial cells apoptosis [15]. Initial studies reported a downregulation in occludin expression in patients with IBD, with no change in claudin-1 expression [16]. However, these TJ modifications might be a consequence of disease pathogenesis rather than a cause, as they were not altered in patients with inactive IBD [17].

Furthermore, several cytokines are known to increase permeability in the intestinal epi- 
thelial monolayer by modulating $\mathrm{TJ}$ protein expression and localization [18]. CD is associated with a $\mathrm{Th}_{1}$-type immune response with excessive production of tumor necrosis factor (TNF) $-\alpha$, interferon (IFN) $-\gamma$ and interleukin-12 (IL-12), whereas ulcerative colitis is the result of a mainly T-helper (Th) 2 , response with abundant IL-5, IL-10 and IL-13 production [19]. In IBD patients, the nuclear factor kappa B (NF- $\kappa \mathrm{B})$ was identified as a key factor in the pro-inflammatory response, resulting in strongly enhanced expression of pro-inflammatory genes and recruitment of the excess inflammatory cells to the intestinal wall [20].

\section{Current and emerging drugs for the treatment of the inflammatory bowel disease}

Treatment of IBD is difficult due to the ambiguity surrounding its precise etiology. Treatment of IBD includes conservative measures as well as surgical approaches in those who are non-responders to medical treatment. Pharmaceutical treatment of the disease includes anti-inflammatory drugs (mesalazine, corticosteroids), immunosuppressives (methotrexate, cyclosporin, azathioprine and 6-mercaptopurine), biologic agents (tumor necrosis factor alpha blocking strategies - infliximab, adalimumab), antibiotics (ciprofloxacin, metronidazole, ornidazole, clarithromycin), and drugs for symptomatic relief [21]. These agents vary in their ability to maintain the control of symptoms as well as in tolerability and toxicities. None of these treatments is effective in all patients and all treatments are associated with a number of disadvantages, including a considerable burden of side effects, highlighting the need for novel treatment options in IBD [22]. Accordingly, future therapy should focus not only on symptomatic relief, but also on rectifying the disturbances in body physiology and associated short and long term complications. The future therapy should also focus on normalizing gut disturbed immune response, which can be achieved through normalizing the composition of gut microflora, gut immune-response and microflora-epithelial interactions towards maintaining normal biochemical reactions and healthy body physiology. Recently, the applications of probiotics that selectively manipulate the gut microflora have gained great interest due to the feasibility of their administration and their safety as well [23]. These agents may become a component of treating IBD in combination with traditional anti-inflammatory and immunosuppressive agents [24].

\section{THE ROLE OF INTESTINAL MICROFLORA AND PROBIOTICS IN IBD}

\section{Gut microflora}

Gut microflora is a complex ecosystem which consists of various microorganisms residing in or passing through the gastrointestinal tract [4]. The human microflora contains upwards of $10^{14}$ microorganisms. It has been suggested that the collection of microbial genes in our bodies exceeds our own genes by a factor of 100 [25]. The microflora colonizes our skin, genitourinary, gastrointestinal, and respiratory tracts. By far the most heavily colonized organ is the gastrointestinal tract; the colon alone is estimated to contain over $70 \%$ of all the microbes in the human body [26]. The human gut microflora comprises a diverse collection of species that are mostly bacteria [27]. The intestinal bacteria consists mainly of obligate anaerobes such as Bacteroides, Eubacterium, Lactobacillus, Bifidobacterium and Clostridium. Facultative anaerobes, e.g. Escherichia coli, are also present [28]. Each individual organism presents a specific "bacterial fingerprint," which is affected by a number of factors including host genotype, antibiotic treatment, diet and the maternal environment [29].

Commensal microorganisms have co-evolved with their host and are essential for development of healthy gut and normal daily function of the human gastrointestinal tract such as digestion, absorption, function of the immune system as well as protection against pathogen colonization [3]. They synthesize compounds such as vitamin $\mathrm{K}$ and $\mathrm{B}$ vitamins, break down cholesterol, produce short chain fatty acids such as butyrate, and digest dietary polysaccharides that would not otherwise be salvageable for energy use [30]. A well balanced diversity of gut microflora is an important aspect of health. In the healthy state, potentially pathogenic bacteria are kept under control by the non-pathogenic flora, so called colonization resistance. Diversity is, however, challenged in some states such as IBD. When such changes 
occur, they affect the host through the intestinal flora's interplay with the body's immune system and through bacterial translocation [31]. As gut microflora appears to play an important role in the pathogenesis, complications and symptoms of IBD, its manipulation by administering beneficial bacteria-probiotics, has been identified as a potential therapeutic option for IBD. Probiotics offer a method to potentially alter the intestinal microbiome exogenously or may provide an option to deliver microbial metabolic products to alter the chronicity of the intestinal mucosal inflammation characterizing the IBD [32].

\section{Probiotics}

\section{General aspects}

Probiotics are dietary supplements containing bacteria which, when administered in adequate amounts, confer a health benefit on the host. Combinations of different bacterial strains can be used but a mixture of Lactobacilli and Bifidobacteria, which have a long and safe history in the manufacture of dairy products, is a common choice [23]. Less commonly used are the bacterial strains of Enterococcus, Bacillus, Streptococcus, Lactococcus, and Escherichia among others. The yeast Saccharomyces boulardi is also used as a human probiotic, in the forms of capsules or powders rather than in food form [33]. The use of probiotics has many potential benefits including modified host metabolism, immuno-stimulation, anti-inflammatory reactions, exclusion and killing of pathogens in the intestinal tract, enhanced nutrient absorption and performance, and ultimately decreased human health risk [34].

\section{Mechanism of probiotic action in IBD}

Probiotic bacteria have been shown to be able to modify and improve the intestinal environment and subsequently reduce the severity of intestinal inflammation associated with IBD. Clinical evidence suggests that probiotics can maintain remission in UC and CD but there are no convincing reports on effectiveness in patients with more severe active forms of IBD [3].

Several probiotic mechanisms of action, relative to inflammatory bowel disease, have been elucidated: (1) competitive exclusion, whereby probiotics compete with microbial pathogens for a limited number of receptors present on the surface epithelium; (2) probiotic-induced sup- pression of pathogen growth through release of antimicrobial factors such as lactic and acetic acid, hydrogen peroxide, and bacteriocins; (3) immunomodulation of an immune response of gut-associated lymphoid and epithelial cells; and (4) enhancement of barrier function. Furthermore, positive effects may be achieved through active constituents of bacteria such as different enzymes, secreted protein factors and bacterial formulated peptides [35]. Each probiotic has a different mechanism of action and as such, not all probiotics will have the same effect after ingestion. Some beneficial effects are common to several probiotic species, while others are specific to particular species [6].

\section{Competitive exclusion}

One general mechanism of probiotic action is an adherence to the intestinal epithelium, which not only stimulates the immune system but also blocks pathogenic bacteria binding to epithelium and subsequent infection. Evidence for this mechanism has been demonstrated in various in vitro systems, for instance, Lactobacillus rhamnosus GG, L. rhamnosus LC705, Bifidobacterium breve 99, and Propionibacterium freudenreichii ssp. shermanii JS have all been demonstrated to reduce the adhesion of a number of pathogenic species to human intestinal mucus [36].

\section{Probiotic-induced suppression \\ of pathogen growth}

Some probiotics can directly kill or inhibit growth of pathogenic bacteria through the release of antimicrobial factors such as lactic and acetic acid, hydrogen peroxide, and bacteriocins $[14,35,37]$. The bacteriocin family is a group of proteins which vary in size, biochemical properties, microbial target and mode of action. Generally, they are most active against closely related bacterial species occupying the same ecological niche and thus have a relatively narrow killing spectrum [38]. The bacteriocin gains entry into the target cell by recognizing the specific cell surface receptors and then kills the cell by several mechanisms: formation of ion-permeable channels in the cytoplasmic membrane, inhibition of protein synthesis through the specific cleavage of $16 \mathrm{~s}$ rRNA, nonspecific degradation of cellular DNA, or cell lysis [39].

Spinler et al. [40] identified production of the potent, broad-spectrum antimicrobial compound reuterin as a mechanism by which Lactobacillus reuteri could exert a beneficial 
effect in the gastrointestinal tract. Furthermore, live $L$. reuteri exhibited greater pathogen-inhibitory activities than reuterin alone, suggesting that other microbial factors were also implicated in the inhibition of bacterial pathogens, and future studies are needed to identify and investigate these compounds [40].

Furthermore, the mechanisms by which probiotic microorganisms are able to modify the intestinal microflora include reduction of luminal $\mathrm{pH}$, thus interfering with the enzymatic activity of the gut flora [4].

\section{Modification of the intestinal immune response}

One of the most interesting characteristics of probiotics is their ability to modify intestinal immune responses that is highly disturbed in patients with IBD. Some strains can interact directly with $\mathrm{T}$ cells or can modify host immune responses indirectly via the modulation of antigen-presenting cells. These actions in turn lead to downstream effects, e.g. they may induce a switch in the $\mathrm{T}$ cell response or modify cytokine profiles [6]. Probiotics can increase levels of IgA-producing cells in the lamina propria and promote secretory $\operatorname{IgA}$ secretion into the luminal mucous layer. These antibodies limit epithelial colonization by binding the bacteria and their antigens, thus contributing to gut homeostasis [14]. Some probiotics may modulate the in vitro expression of pro and anti-inflammatory molecules in a strain-dependent manner. For instance, Lactobacillus sake $i$ induces the expression of IL- $1 \beta$, IL-8 and TNF- $\alpha$, whereas Lactobacillus johnsonii stimulates the production of transforming growth factor (TGF)- $\beta$ in Caco-2 cells [41]. Lorea Baroja et al. [42] described a number of potential mechanisms for the antiinflammatory effect of probiotics, such as modulation of the balance between Th1, Th2, and regulatory T cells; downregulation of proinflammatory cytokine production (e.g., IL-12, TNF- $\alpha$ ) and/ or stimulation of antiinflammatory cytokines (e.g., IL-10); enhanced elimination and permeation of proinflammatory antigens; and as a response to antagonism against potentially pathogenic or proinflammatory endogenous bacteria. The probiotic Bifidobacterium longum down-regulated secretion of proinflammatory TNFa and IL-8 and decreased NF-kB activation in lamina propria mononuclear cells from the inflamed tissues of patients with the active ulcerative colitis [43].

\section{Enhancement of epithelial barrier}

One of the proposed mechanisms how probiotics act in the treatment of IBD is through the enhancement of epithelial barrier. Numerous studies have shown that probiotics have the potential to modulate many of the processes involved in mucosal barrier [3] by affecting the signalling pathways that lead to enhanced mucus or defensin production, or by preventing apoptosis or they may increase TJ function [44]. First, probiotics may promote mucin expression and secretion by goblet cells [14]. Mucins function, in part, by protecting the epithelial surface from the chemical, enzymatic, and microbial damage and have also been shown to inhibit bacterial translocation. In dextran sulfate sodium (DSS) colitis, expression of the goblet cell mucin MUC2, the primary constituent of the colonic protective mucus layer, and trefoil factor 3 , a bioactive peptide involved in epithelial protection and repair, were decreased during the active disease but returned to normal levels during the regenerative phase [13]. Several Lactobacillus species increased mucin expression in the human intestinal cell lines Caco-2 (MUC2) and HT29 (MUC2 and 3), thus blocking the pathogenic E. coli invasion and adherence [32]. Rats fed with VSL\#3 (mixture of 8 different species of bacteria, namely Streptococcus salivarius subsp. thermophilus, Lactobacillus casei, Lactobacillus plantarum, Lactobacillus acidophilus, Lactobacillus delbrueckii subsp. bulgaricus, Bifidobacteria longum, Bifidobacteria infantis, and Bifidobacteria breve) for seven days had elevated MUC2 gene expression leading to an increase in the total mucin pool [45].

Schlee et al. [46] demonstrated that probiotic bacteria (lactobacilli and VSL\#3) may stabilize gut barrier function via induction of anti-microbial peptides such as defensins through the induction of proinflammatory pathways including NF- $\kappa \mathrm{B}$ and activator protein-1 (AP-1) as well as mitogen-activated protein kinase (MAPK).

Furthermore, probiotics can enhance TJ stability, which decreases epithelial permeability to pathogens and their products [14]. The probiotic mixture VSL\#3 was demonstrated to up-regulate the expression of proteins of the TJ, namely of occludin, zonula occludens (ZO)- 1 and claudines $1-5$, thus protecting the rats against an increased intestinal permeability caused by DSS [47]. Ukena et al. [48] showed that treatment with the probiotic E. coli Nissle 
1917 resulted in an increased expression of the TJ molecule ZO-1 at both mRNA and protein levels, and reduced intestinal barrier permeability in mice with DSS-induced experimental colitis. Eun et al. [49] found that probiotic, $L$. casei, prevented TNF- $\alpha$ and IFN- $\gamma$ - induced epithelial barrier dysfunctions including TER, paracellular permeability, and ZO-1 expression in the intestinal epithelial cells. Randomized, crossover study in humans confirmed the role of $L$. plantarum WCFS1 in relocation of ZO-1 and occludin of duodenal cells [50].

\section{Probiotic active constituents}

Recently, there has been a growing interest in the use of probiotic supernatants for the treatment of gastrointestinal disorders. Probiotic supernatants are separated from bacterial cells, but contain a mixture of secreted bacterial products such as short chain fatty acids, phospholipids, bacteriocins and proteins. The advantage of supernatant use would be reduced risk of sepsis associated with the administration of live bacteria as well as facilitated delivery of these secreted products in a more controlled manner, which does not require colonization and survival of bacteria. The exact composition of the secreted products is still unknown, but presumably would vary dependent on species, strain, and culture conditions [51].

Two soluble proteins from Lactobacillus rhamnosus GG, p75 and p40, were demonstrated to promote cell survival and growth in human and mouse colon intestinal epithelial cells. These proteins inhibit TNF- $\alpha$ induced cell apoptosis by activation of the anti-apoptotic factor Akt and protein kinase B. Consequently, colon epithelial damage was significantly reduced by both, p75 and p40 indicating the potential for their use as a new therapeutic for cytokine-mediated gastrointestinal diseases [52].

Lee et al. [53] demonstrated the efficacy of supernatants from L. plantarum HY115 and L. brevis HY7401 in DSS-induced experimental colitic mice by the regulation of the inflammatory cytokine expression via the activation of transcription factor NF-kB. Namely, oral administration of supernatant repressed the mRNA expressions of IL- $1 \beta, \mathrm{TNF} \alpha$, IFN- $\gamma$ mRNA, reduced protein levels of IL- $1 \beta$ and IL- 6 in the colon, and reduced bacterial degradation activities of chondroitin sulfate and hyaluronic acid.

Active constituents of bacteria that manipulate the mucosal immune system include enzymes; secreted protein factors; bacterial formulated peptides such as $\mathrm{N}$-formylmethionineleucine-phenylalanine and lipopolysaccharide and peptidoglycan cell wall constituents including the muramyl dipeptide MurNAc-LAla-DisoGln, gamma-D-glutamyl-meso-diaminopimelic acid and bacterial DNA [35].

These mechanisms indicate that effects of probiotics are strain-specific and they do not act through the same mechanisms [30] but it is obvious that, besides conventional therapy, they might be used as new therapeutic option in patient with IBD.

\section{CONCLUSIONS}

In recent years, a growing body of evidence has implicated gut microflora in the pathogenesis of IBD. Therapeutic manipulation of the intestinal bacteria by administering the beneficial bacteria-probiotics seems to represent a way to treat IBD. The ability of probiotics to increase both intestinal barrier function and antiinflammatory cytokine production makes a promising therapeutic option for IBD. Overall, the existing studies suggest that probiotic use is associated with the similar efficacy profile compared with currently used anti-inflammatory drugs. It is clear from the experimental models that probiotic strains differ greatly in their mechanisms of action, and that a single mechanism of action is unlikely to be responsible for their clinical effects. Future researches need to be focused on obtaining more precise information on the mechanisms of action of probiotics. These findings must be supported by large controlled therapeutic trials using standardized methodology before widespread clinical acceptance.

\section{ACKNOWLEDGMENTS}

This work is supported by the Ministry of Education, Science and Technological Development, Republic of Serbia, Project No. 41012.

\section{Conflict of Interest Statement}

The authors certify that there are no potential conflicts of interest. 


\section{REFERENCES}

1. Day AS, Keenan JI. Probiotic-mediated modulation of host inflammation. Expert Rev Gastroenterol Hepatol. 2011; 5(3):319-21.

2. Laukoetter MG, Nava P, Nusrat A. Role of the intestinal barrier in inflammatory bowel disease. World J Gastroenterol. 2008; 14:401-7.

3. Reiff C, Kelly D. Inflammatory bowel disease, gut bacteria and probiotic therapy. Int I Med Microbiol. 2010; 300(1):25-33.

4. Gerritsen J, Smidt H, Rijkers GT, de Vos WM Intestinal microbiota in human health and disease: the impact of probiotics. Genes Nutr. 2011; 6(3):209-40.

5. Ferreira CL, Salminen S, Grzeskowiak L, Brizuela MA, Sanchez L, Carneiro H, et al. Terminology concepts of probiotic and prebiotic and their role in human and animal health. Rev Salud Anim. 2011; 33(3):137-46.

6. Girardin M, Seidman EG. Indications for the use of probiotics in gastrointestinal diseases. Dig Dis. 2011; 29(6):574-87.

7. Stojančević M, Stankov K, Mikov M. The impact of farnesoid $X$ receptor activation on intestinal permeability in inflammatory bowel disease. Can J Gastroenterol. 2012; 26(9):631-7.

8. Hanauer SB. Inflammatory bowel disease: Epidemiology, pathogenesis, and therapeutic opportunities. Inflamm Bowel Dis. 2006; 12:S3-9.

9. Hendrickson BA, Gokhale R, Cho JH. Clinical aspects and pathophysiology of inflammatory bowel disease. Clin Microbiol Rev. 2002; 15:79-94.

10. Abreu MT. The pathogenesis of inflammatory bowel disease: translational implications for clinicians. Curr Gastroenterol Rep. 2002; 4:481-9.

11. Bourlioux P, Koletzko B, Guarner F, Braesco V. The intestine and its microflora are partners for the protection of the host: report on the Danone Symposium "The Intelligent Intestine", held in Paris, June 14, 2002. Am J Clin Nutr. 2003; 78(4):675-83.

12. Blikslager AT, Moeser AJ, Gookin JL, Jones SL, Podle J. Restoration of barrier function in injured intestinal mucosa. Physiol Rev. 2007; 87:545-64.

13. McCole DF, Barrett KE. Epithelial transport and gut barrier function in colitis. Curr Opin Gastroenterol. 2003; 19:578-82.

14. Ohland CL, Macnaughton WK. Probiotic bacteria and intestinal epithelial barrier function. Am J Physiol Gastrointest Liver Physiol. 2010; 298(6):G807-19.

15. Gitter AH, Bendfeldt K, Schulzke JD, Fromm M. Leaks in the epithelial barrier caused by spontaneous and TNF-alpha-induced single-cell apoptosis. FASEB J. 2000; 14:1749-53.

16. Kucharzik T, Walsh SV, Chen J, Parkos CA, Nusrat A. Neutrophil transmigration in inflammatory bowel disease is associated with differential expression of epithelial intercellular junction proteins. Am J Pathol. 2001; 159:2001-9.

17. Zeissig S, Burgel N, Gunzel D, Richter J, Mankertz J, Wahnschaffe $U$, et al. Changes in expression and distribution of claudin 2, 5 and 8 lead to discontinuous tight junctions and barrier dysfunction in active Crohn's disease. Gut. 2007; 56:61-72.

18. Ceponis PJ, Botelho F, Richards CD, McKay DM. Interleukins 4 and 13 increase intestinal epithelial permeability by a phosphatidylinositol 3-kinase pathway. Lack of evidence for STAT 6 involvement. J Biol Chem. 2000; 275:29132-7.

19. Papadakis KA, Targan SR. Role of cytokines in the pathogenesis of inflammatory bowel disease. Annu Rev Med. 2000; 51:289-98.

20. Rogler G, Brand K, Vogl D, Page S, Hofmeister R, Andus T, et al. Nuclear factor kappaB is activated in macrophages and epithelial cells of inflamed intestinal mucosa. Gastroenterology. 1998; 115:357-69.

21. Triantafillidis JK, Merikas E, Georgopoulos F. Current and emerging drugs for the treatment of inflammatory bowel disease. Drug Des Devel Ther. 2011; 5:185-210.

22. Hedin C, Whelan K, Lindsay JO. Evidence for the use of probiotics and probiotics in inflammatory bowel disease: a review of clinical trials. Proc Nutr Soc. 2007; 66(3):307-15.

23. Al-Salami H, Caccetta R, Golocorbin-Kon S, Mikov M. Probiotics applications in autoimmune diseases. In: Rigobelo EC, editor. Probiotics. Rijeka: InTech; 2012. p. 325-366. [Available from: http://cdn.intechopen.com/pdfs/39618/ InTech-Probiotics_applications_in_autoimmune_ diseases.pdf]

24. Hammer HF. Gut microbiota and inflammatory bowel disease. Dig Dis. 2011; 29(6):550-3.

25. Stojančević M, Bojić G, Al-Salami H, Mikov M. The influence of intestinal tract and probiotics on the fate of orally administered drugs. Curr Issues Mol Biol. 2013; 4:16(2):55-68.

26. Sekirov I, Russell SL, Antunes LCM, Finlay BB. Gut microbiota in health and disease. Physiol Rev. 2010; 90:859-904.

27. Wallace TC, Guarner F, Madsen K, Cabana MD, Gibson G, Hentges E, et al. Human gut microbiota and its relationship to health and disease. Nutr Rev. 2011; 69(7):392-403.

28. Wang M, Ahrné S, Jeppsson B, Molin G. Comparison of bacterial diversity along the human intestinal tract by direct cloning and sequencing of $16 \mathrm{~S}$ rRNA genes. FEMS Microbiol Ecol. 2005; 54(2):219-31.

29. Behnsen J, Deriu E, Sassone-Corsi M, Raffatellu M. Probiotics: properties, examples, and specific applications. Cold Spring Harb Perspect Med. 2013; 3(3):a010074.

30. Petrof EO. Probiotics and gastrointestinal disease: clinical evidence and basic science. Antiinflamm Antiallergy Agents Med Chem. 2009; 8(3):260-9.

31. Lozupone CA, Stombaugh JI, Gordon JI, Jansson JK, Knight R. Diversity, stability and resilience of the human gut microbiota. Nature. 2012; 489(7415): 220-30.

32. Mack DR, Ahrne S, Hyde L, Wei S, Hollingsworth MA. Extracellular MUC3 mucin secretion follows adherence of Lactobacillus strains to intestinal epithelial cells in vitro. Gut. 2003; 52:827-33.

33. Pavlović N, Stankov K, Mikov M. Probiotics interactions with bile acids and impact on cholesterol metabolism. Appl Biochem Biotechnol. 2012; 168(7):1880-95.

34. Al-Salami H, Butt G, Tucker I, Golocorbin-Kon S, Mikov M. Probiotics decreased the bioavailability of the bile acid analog, monoketocholic acid, when coadministered with gliclazide, in healthy but not diabetic rats. Eur J Drug Metab Pharmacokinet. 2012; 37(2):99-108

35. Fedorak RN, Madsen KL. Probiotics and the management of inflammatory bowel disease. Inflamm Bowel Dis. 2004; 10(3):286-99. 
36. Collado M, Meriluoto J, Salminen S. In vitro analysis of probiotic strain combinations to inhibit pathogen adhesion to human intestinal mucus. Food Res Int. 2007; 40:629-36.

37. Chichlowski M, Hale LP. Bacterial-mucosal interactions in inflammatory bowel disease: an alliance gone bad. Am J Physiol Gastrointest Liver Physiol. 2008; 295(6):G1139-49.

38. Gillor O, Etzion A, Riley MA. The dual role of bacteriocins as anti- and probiotics. Appl Microbiol Biotechnol. 2008; 81:591-606.

39. Riley MA, Wertz JE. Bacteriocins: evolution, ecology, and application. Annu Rev Microbiol. 2002; 56:117-37.

40. Spinler JK, Taweechotipatr M, Rognerud CL, Ou CN, Tumwasorn S, Versalovic J. Human-derived probiotic Lactobacillus reuteri demonstrate antimicrobial activities targeting diverse enteric bacterial pathogens. Anaerobe. 2008; 14:166-71.

41. Delcenserie V, Martel D, Lamoureux M, Amiot J, Boutin Y, Roy D. Immunomodulatory effects of probiotics in the intestinal tract. Curr Issues Mol Biol. 2008; 10(1-2):37-54.

42. Lorea Baroja M, Kirjavainen PV, Hekmat S, Reid G. Anti-inflammatory effects of probiotic yogurt in inflammatory bowel disease patients. Clin Exp Immunol. 2007; 149:470-9.

43. Bai AP, Ouyang Q, Xiao XR, Li SF. Probiotics modulate inflammatory cytokine secretion from inflamed mucosa in active ulcerative colitis. Int J Clin Pract. 2006; 60(3):284-8.

44. Bron PA, van Baarlen P, Kleerebezem M. Emerging molecular insights into the interaction between probiotics and the host intestinal mucosa. Nat Rev Microbiol. 2011; 10(1):66-78.

45. Atuma C, Strugala V, Allen A, Holm L. The adherent gastrointestinal mucus gel layer: thickness and physical state in vivo. Am J Physiol Gastrointest Liver Physiol. 2001; 280(5):G922-9.
46. Schlee M, Harder J, Köten B, Stange EF, Wehkamp J, Fellermann K. Probiotic lactobacilli and VSL\#3 induce enterocyte beta-defensin 2. Clin Exp Immunol. 2008; 151(3):528-35.

47. Mennigen R, Nolte K, Rijcken E, Utech M, Loeffler $B$, Senninger N, et al. Probiotic mixture VSL\#3 protects the epithelial barrier by maintaining tight junction protein expression and preventing apoptosis in a murine model of colitis. Am J Physiol Gastrointest Liver Physiol. 2009; 296(5):G1140-9.

48. Ukena SN, Singh A, Dringenberg U, Engelhardt R, Seidler U, Hansen W, et al. Probiotic Escherichia coli Nissle 1917 inhibits leaky gut by enhancing mucosal integrity. PLoS One. 2007; 2(12):e1308.

49. Eun CS, Kim YS, Han DS, Choi, JH, Lee AR, Park YK. Lactobacillus casei prevents impaired barrier function in intestinal epithelial cells. APMIS. 2011; 119:49-56.

50. Sheth P, Delos Santos N, Seth A, LaRusso NF, Rao RK. Lipopolysaccharide disrupts tight junctions in cholangiocyte monolayers by a c-Src-, TLR4-, and LBP-dependent mechanism. Am J Physiol Gastrointest Liver Physiol. 2007; 293(1):G308-18.

51. Prisciandaro L, Geier M, Butler R, Cummins A, Howarth G. Probiotics and their derivatives as treatments for inflammatory bowel disease. Inflamm Bowel Dis. 2009; 15(12):1906-14.

52. Yan F, Cao H, Cover TL, Whitehead R, Washington MK, Polk DB. Soluble proteins produced by probiotic bacteria regulate intestinal epithelial cell survival and growth. Gastroenterology. 2007; 132(2):562-75

53. Lee HS, Han SY, Bae EA, Huh CS, Ahn YT, Lee JH, et al. Lactic acid bacteria inhibit proinflammatory cytokine expression and bacterial glycosaminoglycan degradation activity in dextran sulfate sodium-induced colitic mice. Int Immunopharmacol. 2008; 8:574-80. 


\title{
Probiotici kao obećavajuća terapija za inflamatornu bolest creva
}

\author{
Momir M. Mikov ${ }^{1,2,3}$, Maja P. Stojančević́ ${ }^{1}$, Gordana M. Bojić ${ }^{4}$ \\ ${ }^{1}$ Zavod za farmakologiju, toksikologiju i kliničku farmakologiju, Medicinski fakultet \\ Univerziteta u Novom Sadu, Novi Sad, Srbija; \\ ${ }^{2}$ School of Pharmacy, Curtin Health Innovation Research Institute, Curtin University, \\ Pert, WA, Australija; \\ ${ }^{3}$ Farmaceutski fakultet Univerziteta u Crnoj Gori, Podgorica, Crna Gora; \\ ${ }^{4}$ Zavod za mikrobiologiju, Institut za javno zdravlje, Medicinski fakultet \\ Univerziteta u Novom Sadu, Novi Sad, Srbija
}

\section{KRATAK SADRŽAJ}

Lečenje hroničnih zapaljenjskih gastrointestinalnih oboljenja, kao što je inflamatorna bolest creva (IBC), teško je zbog nedoumica u vezi s njihovom etiologijom. Složene interakcije genetskih, mikrobioloških i faktora sredine dovode do aktivacije mukoznog imunološkog sistema, što izaziva aktivnu inflamaciju. Uprkos delotvornosti konvencionalne terapije, mogu da nastanu značajna neželjena dejstva, čime se ističe potreba za novim terapijskim pristupima u lečenju IBC. Budući da crevna mikroflora ima važnu ulogu u nastanku IBC, manipulacija njenog sastava i aktivnosti primenom korisnih bakterija - probiotika ustanovljena je kao terapijska mogućnost. Probiotske bakterije mogu da modifikuju i poboljšaju sredinu u crevima, te tako ublaže zapaljenje povezano sa IBC. Klinički dokazi ukazuju na to da probiotici mogu da održe remisiju u ulceroznom kolitisu i Kronovoj bolesti, ali ne postoje ubedljivi dokazi o efikasnosti probiotika kod bolesnika s težim oblicima IBC. U ovom radu dati su pregled različitih mehanizama na koje probiotici mogu da utiču u IBC i rezime savremenog znanja u vezi s ulogom probiotika u IBC. Ključne reči: crevna mikroflora; probiotici; inflamacija; intestinalna barijera; intestinalna permeabilnost 